\title{
A Discussion of Servant and Ethical Leadership Styles
}

\author{
Dr. Ahmet Göçen \\ Education Faculty, Harran University, Turkey \\ agocen@harran.edu.tr
}

\begin{abstract}
With an increasing number of studies on leadership, the concepts of ethics and servant-hood occupy a greater presence in educational management literature. Today's school leader could achieve more recognition, become more credible and legitimate in their schools, with their stand in ethical dilemmas and welcoming the needs of the teachers and learners in the first place. It is believed that servant leadership presents organizations with a chance to attain their goals in ethical leadership practices. When the literature is examined, there seems a tendency to assume servant leadership as an influential factor in ethical outcomes. Thus, this chapter will seek to examine the related terms in ethical and servant leadership, the link between both leadership styles and will explore conceptual and empirical findings related to both leadership styles. The chapter is focused on studies in business and education settings, to give more comprehensive idea to the readers on servant and ethical leadership styles.
\end{abstract}

Keywords: Servant leadership, ethical leadership, schools, teachers

\section{Leadership, Servant-hood and Ethics}

Rost (I995) defined leadership as "good management" based on many other different definitions and explanations in the literature. Today, schools need good management, which requires many positive attributes on the side of school leaders, from serving all stakeholders in line with school goals, to standing in the right place on ethical problems. School leaders help the disadvantaged students and give them chance to get most fromschool 
This is a limited preview of the chapter.

To read the full-text chapter, get access by purchasing this chapter or consider buying the complete book. If your library has subscription to EBSCOhost, the chapter including other chapters of the book can be accessed through your library.

This chapter is a part of the book, 'Innovations in Educational Leadership and Continuous Teachers' Professional Development' ISBN (paperback): 978-8I-948483-2-5; ISBN (ebook): 978-8I' $948483-3-2$

Book DOI: https://dx.doi.org/ro.46679/isbn9788194848325 Chapter DOI: https://dx.doi.org/I0.46679/isbn9788194848325II 
More research is required to examine how servant leadership is linked to ethical leadership (Burton, Welty-Peachey, \& Wells, 20I7), most importantly in causal links but on the qualitative side as well. However, there must be recognition that trying to establish a causal link between two leadership styles may be problematic if it leads to further discussion on "what affects what", although some studies in this paper seem to suggest servant leadership has an effect on ethical leadership. The author has tried to demonstrate servant leadership has positive effects on the outcomes of ethical leadership. While literature generally highlights a positive association between servant leadership and ethical outcomes, along with ethical leadership characteristics, this study suggests the value of further researcher to determine correlational and casual studies links between both leadership types.

As the societal demands for higher levels of ethical behavior increase, servant leadership represents a desirable approach by promoting integrity, helping others, and prioritizing the realization of full potential of followers (Liden et al., 20I5). Schools should be a place to nurture servant-hood and ethics with servant and ethical role models for the future of communities.

\section{References}

Arslan, M. (2019). Main Principles of Islamic Work Ethic and Ethic-Civilizations

Relationship in Ibn Khaldun. Ibn Haldun Çalışmaları Dergisi, 4 (I),IOI-128. Doi: I0.36657/ihcd.20I9.54

Barnabas, A., \& Clifford, P. S. (20I2). Mahatma Gandhi-an Indian model of servant leadership. International journal of leadership studies, $\lambda(2)$, I32-I5O.

Brown, M. E., Treviño, L. K., छ Harrison, D. A. (2005). Ethical leadership: A social learning perspective for construct development and testing. Organizational behavior and human decision processes, $97(2)$, II7-134.

Brumley, C. (20II). Leadership Standards in Action : The School Principal as ServantLeader, REL Education, ProQuest Ebook Central, http://ebookcentral.proquest.com/lib/harran/detail.action?docID=860080.

Burton, L. J., Welty-Peachey, J., \& Wells, J. E. (20I7). The role of servant leadership in developing an ethical climate in sport organizations. Journal of Sport Management, 3I(3), 229-240. https://doi.org/I0.II23/jsm.2016-0047 
Cerit, Y. (20I0). The effects of servant leadership on teachers' organizational commitment in primary schools in Turkey. International Journal of Leadership in Education, I3(3), 30I-3I7.

Çimen, B., छ઼ Karadağ, E. (20I9). Özel okul müdürlerinin etik davranışları üzerine bir

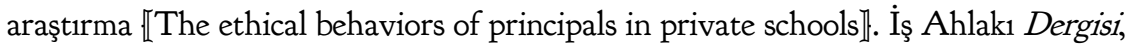
DOI: I0.I27II/tjbe.20I9.I2.I.0I25

Dodd, R., Achen, R. M., छ Lumpkin, A. (2018). Servant leadership and its impact on ethical climate. The Journal of Values-Based Leadership, II(I), I-22.

Ertel, S. (20I7). Why Servant Leadership?. Servant Leadership: Theory E Practice, 4(2), I2. Göçen, A. E̋ Kaya, A. (2oI9, Nov. 3). Okul Yöneticilerinin Hizmetkar Liderlik Davranışlarına İlişkin Öğretmen Görüşleri 〔Teachers' Perceptions on Servant Leadership Behaviors of School Administrators》, 6. Uluslararası Bilimsel Araştırmalar Kongresi, Harran Üniversitesi, Şanliurfa / Turkey

Gorlewski J.A., Gorlewski D.A., Ramming T.M. (2012) Standard 5. In: Theory into Practice. Constructing Knowledge (Curriculum Studies in Action), SensePublishers: Rotterdam.

Greenleaf, R. K. (1970). The servant as leader. Cambridge, MA: Center for Applied Studies.

Greenleaf, R. K. (1977). Servant leadership: A journey into the nature of legitimate power and greatness. New York, NY: Paulist Press.

Griffith, S.D. (2007). Servant leadership, ethics, and the domains of leadership. Presented at Servant Leadership Research Roundtable at Regent University. Retrieved from http://www.regent.edu/acad/global/publications/sl_proceedings/2007/griffit h.pdf.

Güçel, C., Tokmak, İ., छ઼ Turgut, H. (20I2). The relationship of the ethical leadership among the organizational trust, affective commitment and job satisfaction: Case study of a university. International Journal of Social Sciences and Humanity Studies, 4(2), IOI-IIO.

Güngör, S. K. (20I6). The prediction power of servant and ethical leadership behaviours of administrators on teachers' job satisfaction. Universal Journal of Educational Research, 4(5), II80-II88.

Hoch, J. E., Bommer, W. H., Dulebohn, J. H., छु Wu, D. (2018). Do ethical, authentic, and servant leadership explain variance above and beyond transformational leadership? A meta-analysis. Journal of Management, 44(2), 50I529.https://doi.org/IO.II77/014920631666546I

Insley, R., Iaeger, P., Ekinci, A., EJ Sakiz, H. (20I6). An evaluation of teachers' opinions about the servant leadership behaviours of school principals. Educational Process: International Journal, 5(3), 223-235. https://doi.org/I0.12973/edupij.2016.53.4

Jaramillo, F., Bande, B., and Varela, J. (20I5). Servant leadership and ethics: A dyadic examination of supervisor behaviors and salesperson perceptions. Journal of 
Personal Selling and Sales Management, 35, 108-124.

https://doi.org/10.1080/08853134.2015.1010539

Jaramillo, F., Grisaffe, D. B., Chonko, L. B., छ̋ Roberts, J. A. (2009). Examining the impact of servant leadership on salesperson's turnover intention. Journal of Personal Selling Ev Sales Management, 29(4), 35I-365. https://doi.org/I0.2753/PSSo885-3134290404

Kahveci, H., छ Aypay, A. (20I3). Hizmetkâr liderlik ve okul kültürü arasındaki ilişkinin ilköğretim okullarında incelenmesi «An investigation of relationship between the servant leadership and school culture in primary schools]. Eğitimde Politika Analizi, 2(I), 44-60.

Kalshoven, K., Den Hartog, D. N., \& De Hoogh, A. H. (20II). Ethical leadership at work questionnaire (ELW): Development and validation of a multidimensional measure. The Leadership Quarterly, 22(I), 51-69.

Keith, K. M. (20I4). The Ethical Advantage of Servant Leadership. Greenleaf Centre for Servant Leadership (Asia).

Liden, R. C., Wayne, S. J., Meuser, J. D., Hu, J., Wu, J., छ Liao, C. (2015). Servant leadership: Validation of a short form of the SL-28. The Leadership Quarterly, 26(2), 254-269. https://doi.org/Io.IoI6/j.leaqua.20I4.I2.002

Liden, R. C., Wayne, S. J., Zhao, H., छ Henderson, D. (2008). Servant leadership:

Development of a multidimensional measure and multi-level assessment. The Leadership Quarterly, I9(2), I6I-I77. https://doi.org/I0.IoI6/j.leaqua.2008.0I.006

Lumpkin, A., छ Achen, R. M. (2018). Explicating the Synergies of Self-Determination Theory, Ethical Leadership, Servant Leadership, and Emotional Intelligence. Journal of Leadership Studies, I2(I), 6-20. https://doi.org/IO.I002/jls.21554

Mete, Y. A. (20I3). Relationship between organizational cynicism and ethical leadership behaviour: A study at higher education. Procedia-Social and behavioral sciences, 89, 476-483.

Mkhize, N. (1998). Culture, Morality and Self, In Search of an Africentric Voice【Unpublished manuscript]. University of Natal-Pietermaritzberg, Department of Psychology, South Africa Initiative.

Muller, R., Smith, E., Lillah, R. (2018) Perceptions regarding the impact of servant leadership on organizational performance in the Eastern Cape. International Journal of Business and Management Studies, IO(I), 46-62. Retrieved from https://dergipark.org.tr/en/pub/ijbms/issue/36084/405169

Northouse, P. G. (2018). Leadership: Theory and practice. Sage Publications.

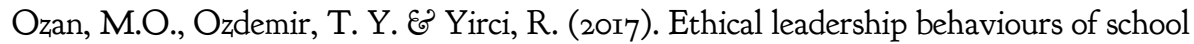
administrators from teachers' point of view. Foro de Educación, I5(23), I6I-184.

Özkan, M.,Temiz, E. (20I7). Teacher's opinions related to servant leadership qualities of primary school principals, Kalem Egitim ve Insan Bilimleri Dergisi, $\lambda(2)$, doi: I0.23863/kalem.20I8.89 
Reed, L. L., Vidaver-Cohen, D., \& Colwell, S. R. (20II). A new scale to measure executive servant leadership: Development, analysis, and implications for research. Journal of business ethics, IOI(3), 415־434. https://doi.org/10.1007/SI055I-010-0729-I

Rost, J.C. (1995). Leadership: A discussion about ethics. Business Ethics Quarterly, 5(I), I29- I42. Retrieved from https://www.jstor.org/stable/3857276

Sağlam, M. H., छ Alpaydın, Y. (20I7). The Relationship between School Administrators Personalities and Servant Leadership Behaviours. Journal of Education and Training Studies, 5(8), I06-II3.

Schwepker, C. H., छ Schultz, R. J. (20I5). Influence of the ethical servant leader and ethical climate on customer value enhancing sales performance. Journal of Personal Selling EO Sales Management, 35(2), 93-107.

Sendjaya, S., Eva, N., Robin, M., Sugianto, L., ButarButar, I., छ Hartel, C. (2020). Leading others to go beyond the call of duty: A dyadic study of servant leadership and psychological ethical climate. Personnel Review, 49(2), 620-635.

https://doi.org/10.1108/PR-08-2018-0285

Shim, D. C., \& Park, H. H. (2019). Public service motivation in a work group: Role of ethical climate and servant leadership. Public Personnel Management, 48(2), 203225. https://doi.org/10.II77/0091026018806013

Spears, L. C. (1995). Reflections on leadership: How Robert K. Greenleaf's theory of servant-leadership influenced today's top management thinkers (No. 658.4092

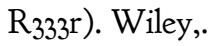

Tabancalı, E., छ̋ Çakıroğlu, Z. K. (20I7). Okul müdürlerinin etik liderlik davranışları ile ögretmenlerin örgütsel vatandaşlık davranışları arasındaki ilişki «Relationship between ethical leadership of school principals and organizational citizenship behaviors of teachers]. Mersin University Journal of the Faculty of Education, I3(I), 392-4I7. https://doi.org/I0.I7860/mersinefd.296254

Tangwa, G. B. (2005). Morality and Culture: Are Ethics Culture-Dependent?. In Bioethics in a small world (pp. I7-21). Springer, Berlin, Heidelberg.

Teyfur, M., Beytekin, O. F., छ Yalçınkaya, M. (20I3). İlköğretim okul yöneticilerinin etik liderlik özellikleri ile okullardaki örgütsel güven düzeyinin incelenmesi (İzmir il örneği) $\llbracket$ A research on the ethical leadership of primary school administrators and the organizational trust levels in primary schools: The sample of İzmir]. Dicle University Journal of Ziya Gokalp Education Faculty, 2I, 84-106

Van Dierendonck, D., \& Patterson, K. (2015). Compassionate Love as a Cornerstone of Servant Leadership: An Integration of Previous Theorizing and Research. Journal of Business Ethics, I28(I), II9-I3I. https://doi.org/I0.1007/sI0551-014-2085-z

Van Heerden, L. D. (2015). The relationship between servant leadership and an ethical work climate in an agri-business (Doctoral dissertation).North-West University: Potchefstroom. 